\title{
Plaque reduction neutralization antibody test does not accurately predict protection against dengue infection in Ratchaburi cohort, Thailand
}

\author{
Chukiat Sirivichayakul ${ }^{1 *}$, Arunee Sabchareon ${ }^{1}$, Kriengsak Limkittikul ${ }^{1}$ and Sutee Yoksan ${ }^{2}$
}

\begin{abstract}
Background: The plaque reduction neutralization test (PRNT) is currently the best and most widely accepted approach to measuring virus-neutralizing and protective antibodies to dengue virus, and in assessing the immunogenicity of a dengue vaccine. However, the correlation between presence of dengue-neutralizing antibody and protection from infection is not absolute.
\end{abstract}

Findings: In a cohort study in Ratchaburi Province, Thailand, 48 subjects with serologically confirmed symptomatic dengue infection were tested for pre-existing dengue neutralizing antibody using PRNT. Nine subjects had quite high pre-existing PRNT50 titers (titer $>90$ ) to subsequent infecting dengue serotypes, but still had symptomatic infections.

Conclusion: This report provides evidence that PRNT may not be a good test for predicting protection against subsequent dengue infection.

Keywords: Dengue, Plaque reduction neutralization test, Neutralizing antibody

\section{Findings}

\section{Background}

The plaque reduction neutralization test (PRNT) is a method for measuring antibodies that neutralize and prevent virions from infecting cultured cells. It is currently the most virus-specific serological test among the flaviviruses, and serotype-specific test among the dengue viruses [1]. PRNT has been widely used in assessing the protective neutralizing antibody response for Japaneseencephalitis vaccines [2-4].

For dengue, PRNT is the best and most widely accepted approach to measuring virus-neutralizing and protective antibodies [1], and assessing the immunogenicity of dengue vaccine [5-8]. However, the correlation between the presence of virus-neutralizing antibody and protection from infection is not absolute. This report aims to provide additional data on the correlation of pre-existing dengueneutralizing antibody and protection from subsequent dengue infection.

\footnotetext{
* Correspondence: chukiat.sir@mahidol.ac.th

${ }^{1}$ Department of Tropical Pediatrics, Faculty of Tropical Medicine, Mahidol University, Bangkok, Thailand

Full list of author information is available at the end of the article
}

\section{Methods}

In the cohort study conducted among school children in Ratchaburi Province, Thailand [9], we prospectively collected serum samples annually from all subjects. Acute and convalescent serum samples were also collected from each febrile subject, irrespective of clinical diagnosis. Clinical diagnosis was performed by a pediatrician who was unaware of the dengue diagnostic test results. Clinical diagnoses of dengue fever (DF), dengue hemorrhagic fever (DHF), and DHF severity were made using the WHO criteria (1997) [10]. All blood samples were drawn into serum separator tubes, allowed to clot at room temperature for $1-2$ hours, then stored at $4^{\circ} \mathrm{C}$. Sera were separated into aliquots within 24 hours and stored at $-70^{\circ} \mathrm{C}$ until laboratory testing. Dengue diagnostic testing was performed at the Center for Vaccine Development, Institute of Molecular Biosciences, Mahidol University, Salaya, Nakhonpathom, Thailand (CVD). Acute and convalescent sera were tested for dengue-virus-specific IgM/ IgG by enzyme-linked immunosorbent assay (ELISA) using slightly modified method from that described previously [11]. The sensitivity of this test was $97 \%$ in paired sera [11]. An IgM anti-dengue level $\geq 1$ unit in acute serum, or seroconversion of either IgM or IgG in paired 
sera, was considered indicative of acute dengue infection. Primary dengue infection was diagnosed when the IgM: IgG ratio was $>1: 1.8$. Serum samples from acute dengue cases were tested for dengue-virus serotype by inoculation into Toxorhynchites splendens mosquitoes with immunofluorescence detection and serotyping [12].

We randomly selected 48 subjects with acute dengue infection in the year 2006. Pre-infection sera were retrieved from the previous annual serum samples and tested for pre-existing dengue- and Japanese encephalitisneutralizing antibody using PRNT, as described by Russell et al. [13]. In the tests, conducted at the CVD, monkey kidney-derived LLC-MK2 cells were used for virus production and PRNT. The dengue viruses (D) used in the assay were D1 (16007), D2 (16681), D3 (16562), and D4 (1036). LLC-MK2 cells were seeded in 6-well plates at $1 \times 10^{5}$ cells/well, and incubated for 6-8 days. Neutralizing sera were diluted to $1: 5$, followed by ten-fold serial dilutions using phosphate buffer solution (PBS) $\mathrm{pH} 7.5$ with $30 \%$ fetal bovine serum, mixed with virus (for a final starting dilution of 1:10), and incubated. Following infection, cells were overlaid with $3.0 \%$ carboxymethyl cellulose with neutral red added. Plaques were visualized and counted after cultivation for 7 days. Data were interpreted using the Probit model with the SPSS program, and PRNT endpoint titers were expressed as the reciprocal of the last serum dilution. The PRNT titer was calculated based on a $50 \%$ reduction in plaque count (PRNT50).

\section{Results}

Tables 1, 2, 3 show the pre-existing dengue PRNT50 titers in the sera of subjects in February 2006, date of subsequent dengue illness, clinical diagnosis, and the serotype isolated. Among 48 subjects with serologically confirmed dengue infection, dengue viruses could be identified in 31 (64.6\%) subjects, comprising 16 D1; 1 D2; 3 D3; and 11 D4. Only 5 (10.4\%) subjects had primary infections.

Table 1 Pre-existing PRNT50 titer and subsequent dengue infection in subjects with low titer $(<90)$ to subsequent infecting serotype

\begin{tabular}{|c|c|c|c|c|c|c|c|c|c|}
\hline \multirow{2}{*}{$\begin{array}{l}\text { Subject } \\
\text { code }\end{array}$} & \multicolumn{5}{|c|}{ PRNT50 titer (Feb 2006) } & \multirow{2}{*}{$\begin{array}{l}\text { Date of } \\
\text { illness }\end{array}$} & \multirow{2}{*}{$\begin{array}{c}\text { Clinical } \\
\text { diagnosis }\end{array}$} & \multirow{2}{*}{$\begin{array}{l}\text { ELISA test } \\
\text { result }^{\mathrm{a}}\end{array}$} & \multirow{2}{*}{$\begin{array}{l}\text { Serotype } \\
\text { isolated }\end{array}$} \\
\hline & D1 & D2 & D3 & D4 & JE & & & & \\
\hline $03-146$ & $<10$ & $<10$ & $<10$ & $<10$ & 155 & $11 / 10 / 2006$ & DF & Secondary & D1 \\
\hline 05-119 & $<10$ & $<10$ & $<10$ & $<10$ & 235 & $9 / 6 / 2006$ & Pharyngitis & Secondary & D1 \\
\hline 05-181 & $<10$ & $<10$ & $<10$ & $<10$ & $<10$ & $21 / 8 / 2006$ & DF & Primary & D1 \\
\hline $05-310$ & 10 & $<10$ & 167 & $<10$ & 250 & $21 / 4 / 2006$ & DF & Secondary & D1 \\
\hline $07-479$ & $<10$ & $<10$ & $<10$ & $<10$ & 29 & $23 / 7 / 2006$ & DF & Secondary & D1 \\
\hline $07-383$ & 13 & $<10$ & $<10$ & $<10$ & $<10$ & 10/9/2006 & DF & Primary & D1 \\
\hline $04-276$ & 13 & $<10$ & $<10$ & $<10$ & $<10$ & $13 / 3 / 2006$ & DF & Primary & D1 \\
\hline $05-357$ & 40 & 29 & 27 & $<10$ & 303 & 10/10/2006 & Bronchitis & Secondary & D1 \\
\hline 05-002 & 50 & $<10$ & $<10$ & $<10$ & 396 & 25/11/2006 & DF & Secondary & D1 \\
\hline 03-097 & 75 & 1134 & 24 & 20 & 1307 & $7 / 10 / 2006$ & DF & Secondary & D1 \\
\hline 05-339 & $<10$ & $<10$ & $<10$ & $<10$ & 503 & 28/8/2006 & Pharyngitis & Secondary & D2 \\
\hline $04-322$ & 17 & $<10$ & $<10$ & $<10$ & 165 & $9 / 11 / 2006$ & DF & Secondary & D3 \\
\hline $04-325$ & $<10$ & $<10$ & $<10$ & $<10$ & 685 & 23/10/2006 & DHF gr2 & Secondary & D3 \\
\hline 02-189 & $<10$ & 10 & 12 & $<10$ & $<10$ & 6/7/2006 & DF & Primary & D3 \\
\hline $01-227$ & 49 & $<10$ & $<10$ & $<10$ & 590 & 19/2/2006 & Pharyngitis & Secondary & D4 \\
\hline $01-254$ & 12450 & 3348 & 32 & $<10$ & 78 & $28 / 2 / 2006$ & AGE & Secondary & D4 \\
\hline $01-384$ & $<10$ & $<10$ & $<10$ & $<10$ & 92 & 19/12/2006 & Pharyngitis & Secondary & D4 \\
\hline 06-164 & 210 & 540 & 12040 & 21 & 76 & $30 / 8 / 2006$ & DF & Secondary & D4 \\
\hline $01-124$ & 228 & 135 & 516 & 39 & 28 & $31 / 3 / 2006$ & DF & Secondary & D4 \\
\hline $05-257$ & 3141 & 194 & 272 & 41 & 726 & 15/10/2006 & Common cold & Secondary & D4 \\
\hline $01-224$ & 195 & 2901 & 220 & 50 & 802 & $9 / 3 / 2006$ & DHF gr1 & Secondary & D4 \\
\hline $05-378$ & 6238 & 2204 & 676 & 75 & 43 & 28/7/2006 & DF & Secondary & D4 \\
\hline
\end{tabular}

${ }^{a}$ ELISA result showed either primary or secondary infection.

AGE: acute gastroenteritis; D: dengue virus; DF: dengue fever; DHF: dengue hemorrhagic fever; gr: grade; JE: Japanese encephalitis virus; PRNT50: 50\% plaque reduction neutralization. 
Table 2 Pre-existing PRNT50 titer and subsequent dengue infection in subjects with high titer (>90) to subsequent infecting serotype

\begin{tabular}{|c|c|c|c|c|c|c|c|c|c|}
\hline \multirow{2}{*}{$\begin{array}{l}\text { Subject } \\
\text { code }\end{array}$} & \multicolumn{5}{|c|}{ PRNT50 titer (Feb 2006) } & \multirow{2}{*}{$\begin{array}{l}\text { Date of } \\
\text { illness }\end{array}$} & \multirow{2}{*}{$\begin{array}{l}\text { Clinical } \\
\text { diagnosis }\end{array}$} & \multirow{2}{*}{$\begin{array}{l}\text { ELISA test } \\
\text { result }^{\mathrm{a}}\end{array}$} & \multirow{2}{*}{$\begin{array}{l}\text { Serotype } \\
\text { isolated }\end{array}$} \\
\hline & D1 & D2 & D3 & D4 & $\mathrm{JE}$ & & & & \\
\hline $06-043$ & 121 & 224 & 83 & $<10$ & 11 & $14 / 8 / 2006$ & DF & Secondary & D1 \\
\hline $05-021$ & 133 & $<10$ & $<10$ & $<10$ & 72 & $26 / 4 / 2006$ & DF & Secondary & D1 \\
\hline $05-074$ & 173 & 1136 & 73 & 31 & 503 & $9 / 5 / 2006$ & DF & Secondary & D1 \\
\hline 06-082 & 317 & $<10$ & 18 & $<10$ & 760 & $14 / 6 / 2006$ & Viral infection & Secondary & D1 \\
\hline $01-286$ & 581 & $<10$ & $<10$ & $<10$ & $<10$ & 19/4/2006 & DF & Secondary & D1 \\
\hline $01-141$ & 1848 & 821 & 4521 & 328 & 738 & $6 / 11 / 2006$ & Pharyngitis & Secondary & D1 \\
\hline $07-119$ & 5291 & 84 & 332 & 98 & 207 & 28/7/2006 & DF & Secondary & D4 \\
\hline $05-244$ & 4916 & 1305 & 1006 & 145 & 393 & 21/9/2006 & DF & Secondary & D4 \\
\hline $04-378$ & 11682 & 853 & 417 & 261 & 5615 & $5 / 7 / 2006$ & DF & Secondary & D4 \\
\hline
\end{tabular}

${ }^{a}$ ELISA result showed either primary or secondary infection.

D: dengue virus; DF: dengue fever; JE: Japanese encephalitis virus; PRNT50: 50\% plaque reduction neutralization.

Of 31 subjects whose infecting dengue serotypes were identified, 14 (45.2\%) had pre-existing PRNT50 titers to the infecting serotype $<20$. Eight subjects $(25.8 \%)$ had pre-existing PRNT50 titers to the infecting serotype of between 21 and 75 (Table 1).

Interestingly, nine (29.0\%) subjects had pre-existing PRNT50 titers of $>90$ to the subsequent infecting serotypes. Six subjects with D1 infections had pre-existing PRNT50 titers to D1, which ranged from 121 to 1848; geometric mean value 313 ; median value 245 . Two subjects (subjects 01-286 and 05-021) had PRNT50 profiles suggesting previous primary D1 infection, but had secondary symptomatic infections with the same serotype. Three subjects with D4 infections had pre-existing PRNT50 titers to D4, ranging between 98 to 261, geometric mean value 154 (Table 2).

It is worth noting that many subjects (e.g. subjects 01-456 and 04-378) had pre-existing PRNT50 profiles

Table 3 Pre-existing PRNT50 titer and subsequent dengue infection among subjects whose subsequent infecting serotypes could not be identified

\begin{tabular}{|c|c|c|c|c|c|c|c|c|}
\hline \multirow{2}{*}{$\begin{array}{l}\text { Subject } \\
\text { code }\end{array}$} & \multicolumn{5}{|c|}{ PRNT50 titer (Feb 2006) } & \multirow{2}{*}{$\begin{array}{l}\text { Date of } \\
\text { illness }\end{array}$} & \multirow{2}{*}{$\begin{array}{l}\text { Clinical } \\
\text { diagnosis }\end{array}$} & \multirow{2}{*}{$\begin{array}{l}\text { ELISA tes } \\
\text { result }^{\mathrm{a}}\end{array}$} \\
\hline & D1 & D2 & D3 & D4 & JE & & & \\
\hline $01-177$ & 537 & 218 & 619 & 74 & 14 & $1 / 6 / 2006$ & Pharyngitis & Secondary \\
\hline $01-437$ & 473 & 297 & 1283 & $<10$ & 75 & 9/9/2006 & Influenza & Secondary \\
\hline $01-456$ & 14105 & 2851 & 7872 & 235 & 594 & $27 / 6 / 2006$ & DF & Secondary \\
\hline $01-559$ & 393 & 1606 & 249 & 65 & 4987 & 14/8/2006 & viral infection & Secondary \\
\hline $02-246$ & $<10$ & $<10$ & 16 & $<10$ & 2201 & $3 / 5 / 2006$ & DF & Secondary \\
\hline $02-434$ & $<10$ & $<10$ & $<10$ & $<10$ & 1326 & $31 / 3 / 2006$ & Pharyngitis & Secondary \\
\hline $02-453$ & 172 & 2053 & 126 & 53 & 14587 & 10/3/2006 & DHF gr3 & Secondary \\
\hline 03-021 & 867 & $<10$ & 1026 & $<10$ & $<10$ & 29/11/2006 & DHF gr1 & Secondary \\
\hline $05-072$ & 351 & 36 & $<10$ & 174 & 140 & $1 / 12 / 2006$ & Viral infection & Secondary \\
\hline 05-0112 & $<10$ & $<10$ & $<10$ & $<10$ & $<10$ & $2 / 12 / 2006$ & URI & Primary \\
\hline $05-209$ & 310 & 48 & 753 & 14 & 76 & 29/7/2006 & DHF gr1 & Secondary \\
\hline $05-239$ & 3257 & 8199 & 111 & 40 & 919 & 24/4/2006 & DHF gr1 & Secondary \\
\hline $05-358$ & 249 & 247 & 3934 & 34 & 267 & 10/6/2006 & Viral infection & Secondary \\
\hline $06-070$ & 236 & 2687 & 10649 & $<10$ & 94 & $16 / 6 / 2006$ & Pharyngitis & Secondary \\
\hline $06-124$ & 472 & 5074 & 3943 & 29 & 164 & 27/8/2006 & DHF gr1 & Secondary \\
\hline 06-192 & 10 & $<10$ & $<10$ & $<10$ & 42 & 26/8/2006 & Pharyngitis & Secondary \\
\hline $07-310$ & 137 & 43 & 23 & 198 & 21 & 7/8/2006 & Influenza & Secondary \\
\hline
\end{tabular}

${ }^{a}$ The ELISA result showed either primary or secondary infection.

D: dengue virus; DF: dengue fever; DHF: dengue hemorrhagic fever; gr: grade; JE: Japanese encephalitis virus; PRNT50: $50 \%$ plaque reduction neutralization. 
suggesting secondary dengue infection, but still had symptomatic infections, which were probably tertiary infections (Tables 3 and 2, respectively).

\section{Discussion}

Dengue viruses comprise 4 serotypes. Infection with one dengue serotype elicits lifelong homotypic immunity, but only short-lived immunity for heterotypic serotypes [14]. Dengue neutralizing antibody has been believed to represent protection against dengue, and the PRNT test has been widely used to measure this neutralizing antibody. Numerous vaccine immunogenicity assessment laboratories consider a seropositive threshold to be 10 [1] and since four of the subjects in this report had PRNT50 titers of 10-13, we arbitrarily divided the subjects into 3 groups, i.e. titer $<20,20-90$, and $>90$. We found that 17 $(54.8 \%)$ and $9(29.0 \%)$ of 31 subjects had pre-existing PRNT50 titers $>20$ and $>90$, respectively, to the subsequent infecting dengue serotype. These data provide partial insight into the correlation between PRNT50 titer and disease protection. This is very important, because PRNT titer is considered an important marker of protection in the development of dengue vaccines. These data are perhaps the most relevant available data, as more valid data on the correlation between pre-existing PRNT50 titer and disease protection in humans requires human challenge with dengue virus, which may not be possible due to ethical issues. This report raises some inconsistencies with our previous understandings. First, the finding in 2 subjects (subjects 01-286 and 05-021 [Table 2]) suggests that previous D1 infection may not induce protection to subsequent symptomatic homotypic dengue infection. Second, a quite high pre-existing PRNT50 titer (>90) may not be able to protect against subsequent symptomatic infection from the respective dengue serotype.

In a cohort study in Thailand, Endy et al. [15] also found that pre-existing neutralizing antibody directed against infecting dengue serotype (titer $>10$ ) was detected in $36 \%, 67 \%$, and $46 \%$ of D3, D2, and D1 infections, respectively. Moreover, only a pre-existing PRNT50 > 100 against the reference D3 strain was associated with milder severity of disease, but not in D2 and D1. This is further confirmed by the finding in a phase- $2 \mathrm{~b}$ dengue-vaccine trial among Thai children that the tetravalent liveattenuated dengue vaccine had a low level of efficacy against D2, despite its high immunogenicity [16].

There are some possible explanations for the lack of a definite correlation between PRNT50 titer and protection from subsequent dengue infection. One possible explanation is that in our PRNT, we used LLC-MK2 cells, which are not FcyR-expressing cells. In the absence of $F c \gamma R$, dengue virus-antibody complexes are not able to infect the cells, while these complexes are taken up more efficiently by Fc $\gamma \mathrm{R}$-expressing cells, and are still infectious [17]. This is supported by the study of Moi et al. [18], who found that 11 of 18 serum samples from patients with acute secondary dengue infection demonstrated neutralizing activity to the infecting serotype, determined using FcyR-negative BHK cells, but not when determined using Fc $\gamma \mathrm{R}$-expressing cells. Another explanation is that the protective PRNT50 titer for dengue may be much higher than the titer of 10 , defined for Japanese encephalitis virus, and the protective level of dengue neutralizing antibody should be more accurately defined. This study revealed that subjects with preexisting PRNT50 titer of up to 1848 against D1, and 261 against D4, still had symptomatic infections due to the respective serotypes, suggesting the protective level should be higher and may differ for different serotypes. Nevertheless, defining the protective-level cut-off point is difficult and challenging. A very large cohort study and long-term follow-up are needed, unless a challenge test in subjects with pre-defined PRNT levels could be conducted. Moreover, as PRNT titers vary significantly depending on testing conditions, such as virus strains, virus passage and cell type $[19,20]$, optimal testing conditions should be defined.

Finally, the pre-infection PRNT50 titers are against reference dengue-virus strains. As molecular evolution among dengue viruses has been continuous [21], it may cause antigenic mismatches between the reference dengue virus strains used in the PRNT and infecting viruses, and therefore, mismatch between the pre-existing antibody and the antigen of the infecting homologous serotype. Further studies are needed to clarify these possibilities.

It is also noted that dengue-naïve but Japanese encephalitis (JE)-immuned subjects shown by PRNT (e.g. subjects 01-384, 04-325, 07-479) showed secondary antibody response to subsequent dengue infection. One subject (subject 04-325) had DHF grade2. These pieces of evidence suggest cross-reactive antibody responses between dengue and JE.

\section{Competing interests}

The authors declare that they have no competing interests.

\section{Authors' contributions}

CS, AS and KL designed the study, collected data and specimens, wrote and reviewed the manuscript. SY performed laboratory tests, wrote and reviewed the manuscript. All authors read and approved the final manuscript.

\section{Acknowledgements}

We thank all subjects and their families for participating in this study and the staff of Ratchaburi Hospital for data collection. We also thank Mr. Paul R Adams for editing this manuscript. This study was funded by the Thai Ministry of Public Health, the Pediatric Dengue Vaccine Initiative, and the Faculty of Tropical Medicine, Mahidol University, Thailand. The funders played no role in study design, or data collection, analysis and interpretation. 


\section{Author details}

${ }^{1}$ Department of Tropical Pediatrics, Faculty of Tropical Medicine, Mahidol University, Bangkok, Thailand. ${ }^{2}$ Center for Vaccine Development, Mahidol University, Nakhonpathom, Thailand.

Received: 22 November 2013 Accepted: 7 March 2014 Published: 12 March 2014

\section{References}

1. Roehrig JT, Hombach J, Barrett AD: Guidelines for plaque-reduction neutralization testing of human antibodies to dengue viruses. Virol Immunol 2008, 21:123-132.

2. Reisler RB, Danner DK, Gibbs PH: Immunogenicity of an inactivated Japanese encephalitis vaccine (JE-VAX) in humans over 20 years at USAMRIID: using PRNT50 as an endpoint for immunogenicity. Vaccine 2010, 28:2436-2441.

3. Eder S, Dubischar-Kastner K, Firbas C, Jelinek T, Jilma B, Kaltenboeck A Knappik M, Kollaritsch H, Kundi M, Paulke-Korinek M, Schuller E, Klade CS: Long term immunity following a booster dose of the inactivated Japanese Encephalitis vaccine IXIARO ${ }^{\circledR}$, IC51. Vaccine 2011, 29:2607-2612.

4. Feroldi E, Pancharoen C, Kosalaraksa P, Watanaveeradej V, Phirangkul K, Capeding MR, Boaz M, Gailhardou S, Bouckenooghe A: Single-dose, live-attenuated Japanese encephalitis vaccine in children aged 12-18 months: randomized, controlled phase 3 immunogenicity and safety trial. Hum Vaccin Immunother 2012, 8:929-937.

5. Kochel TJ, Raviprakash K, Hayes CG, Watts DM, Russell KL, Gozalo AS, Phillips IA Ewing DF, Murphy GS, Porter KR: A dengue virus serotype-1 DNA vaccine induces virus neutralizing antibodies and provides protection from viral challenge in Aotus monkeys. Vaccine 2000, 18:3166-3173.

6. Sabchareon A, Lang J, Chanthavanich P, Yoksan S, Forrat R, Attanath P, Sirivichayakul C, Pengsaa K, Pojjaroen-Anant C, Chambonneau L, Saluzzo JF, Bhamarapravati N: Safety and immunogenicity of a three dose regimen of two tetravalent live-attenuated dengue vaccines in five- to twelve-year-old Thai children. Pediatr Infect Dis J 2004, 23:99-109.

7. WHO: Dengue: guidelines for diagnosis, treatment, prevention and control; 2009. http://whqlibdoc.who.int/publications/2009/9789241547871_eng.pdf.

8. Guy B, Saville M, Lang J: Development of Sanofi Pasteur tetravalent dengue vaccine. Hum Vaccin 2010, 6(9):696-705.

9. Sabchareon A, Sirivichayakul C, Limkittikul K, Chanthavanich P, Suvannadabba S, Jiwariyavej V, Dulyachai W, Pengsaa K, Margolis HS, Letson GW: Dengue infection in children in Ratchaburi, Thailand: a cohort study. I. Epidemiology of symptomatic acute dengue infection in children, 2006-2009. PLOS Negl Trop Dis 2012, 6:e1732.

10. World Health Organization: Dengue hemorrhagic fever: diagnosis, treatment, prevention and control. Geneva: WHO; 1997.

11. Innis BL, Nisalak A, Nimmannitya S, Kusalerdchariya S, Chongswasdi V, Suntayakorn S, Puttisri P, Hoke CH: An enzyme-linked immunosorbent assay to characterize dengue infections when dengue and Japanese encephalitis co-circulate. Am J Trop Med Hyg 1989, 40:418-427.

12. Rosen $L$ : The use of Toxorhynchites mosquitoes to detect and propagate dengue and other arboviruses. Am J Trop Med Hyg 1981, 30:177-183.

13. Russell PK, Nisalak A, Sukhavachana P, Vivona S: A plaque reduction test for dengue virus neutralizing antibodies. J Immunol 1967, 99:285-290.

14. Sabin AB: Research on dengue during World War II. Am J Trop Med Hyg 1952, 1:30-50.

15. Endy TP, Nisalak A, Chunsuttitwat S, Vaughn DW, Green S, Ennis FA, Rothman AL, Libraty DH: Relationship of preexisting dengue virus (DV) neutralizing antibody levels to viremia and severity of disease in a prospective cohort study of DV infection in Thailand. J Infect Dis 2004, 189:990-1000

16. Sabchareon A, Wallace D, Sirivichayakul C, Limkittikul K, Chanthavanich P, Suvannadabba S, Jiwariyavej V, Dulyachai W, Pengsaa K, Wartel TA, Moureau A, Saville M, Bouckenooghe A, Viviani S, Tornieporth NG, Lang J: Protective efficacy of the recombinant, live-attenuated, CYD tetravalent dengue vaccine in Thai schoolchildren: a randomised, controlled phase 2b trial. Lancet 2012, 380:1559-1567.

17. Rodrigo WW, Jin X, Blackley SD, Rose RC, Schlesinger JJ: Differential enhancement of dengue virus immune complex infectivity mediated by signaling-competent and signaling-incompetent human Fcgamma RIA (CD64) or FcgammaRIIA (CD32). J Virol 2006, 80:10128-10138.
18. Moi ML, Lim CK, Chua KB, Takasaki T, Kurane I: Dengue virus infection-enhancing activity in serum samples with neutralizing activity as determined by using FcyR-expressing cells. PLOS Negl Trop Dis 2012, 6:e1536.

19. Thomas SJ, Nisalak A, Anderson KB, Libraty DH, Kalayanarooj S, Vaughn DW Putnak R, Gibbons RV, Jarman R, Endy TP: Denque plaque reduction neutralization test (PRNT) in primary and secondary dengue virus infection: how alteration in assay conditions impact performance. Am J Trop Med Hyg 2009, 81:825-833.

20. Rainwater-Lovett K, Rodriguez-Barraquer I, Cummings DA, Lessler J: Variation in dengue virus plaque reduction neutralization testing: systematic review and pool analysis. BMC Infect Dis 2012, 12:233.

21. Chen SP: Molecular evolution and epidemiology of four serotypes of dengue virus in Thailand from 1973 to 2007. Epidemiol Infect 2012, 14:1-6.

doi:10.1186/1743-422X-11-48

Cite this article as: Sirivichayakul et al.: Plaque reduction neutralization antibody test does not accurately predict protection against dengue infection in Ratchaburi cohort, Thailand. Virology Journal 2014 11:48.

\section{Submit your next manuscript to BioMed Central and take full advantage of:}

- Convenient online submission

- Thorough peer review

- No space constraints or color figure charges

- Immediate publication on acceptance

- Inclusion in PubMed, CAS, Scopus and Google Scholar

- Research which is freely available for redistribution

Submit your manuscript at www.biomedcentral.com/submit
C Biomed Central 